\title{
Big Data Analytics for Enhancing Students Experience in Higher Education - A Case Study
}

\author{
Teba Fadhil Muhsin \\ Anjum Zameer Bhat \\ Imran Ahmed Mohamed \\ Samiulla Khan
}

\author{
Middle East College \\ Middle East College \\ Middle East College
}

\begin{abstract}
Big Data analytics in the recent past has evolved as an innovative branch in the field of information technology that has contributed in a significant manner to various areas of human endeavor. Some of the evident sectors in which big data is contributing in huge manner are natural disaster management and forecast, healthcare, agriculture, insurance, welfare schemes, cyber security, banking and many others. The education sector one amongst the other areas which has huge scope for enhancement by implementation of big data analytics. Big data analytics can provide insights about various unknown facts which can result in enhancement of student learning, better classroom planning, enhancement in lecture delivery and overall enhancement of student experience. Moreover, it can also result in easy decision making for management in a higher education institution and less administrative work for academic staff. This research is aligned in the same direction where a sample group of students in higher education are monitored with sensing devices to observer their attention levels while various pedagogical approaches are adopted for the comparison. This research yields specific facts about student attention levels based on the analysis that is done using SPSS analysis tool. This research considers students at different levels of bachelors study program in a higher education institution and monitors same cohort of student with various pedagogical methodologies. This research work is a mere effort to enhance student experience in higher education institutions by analyzing different learning approaches with student's attention levels.
\end{abstract}

\section{Introduction}

New technologies started to be a part of and used in learning and educational systems at the beginnings of the 21st century, to support the human evolution, to raise the quality level of the education being provided to the students, and to give the students to opportunity to study what they likely good at and what would benefit them the most according to their skills. Modern technologies started to integrate with many various life matters, it became a main part the humanity cannot go on without it, now we have innovative technologies used in medical sectors, technologies used in security systems, technology used in banking sectors, and of course it started to integrate with the educational system in general and the higher education systems in specific due to the variety of advantages and benefits it is providing to the learning system, and at this point a new term of education was created which is Smart Learning/Education. (Al-Awar, 2015).

The term Smart Learning refers to the use and the assist of various modern technologies in the education and learning sector, modern technologies such as wireless devices, internet, IoT, Big Data Analytics etc..., in order to provide variety of powerful learning methods and techniques to the different types of students, and provide them the opportunity to choose their majors and the best suitable teaching methods according to their skills, and allow them to not only receive the 
information and solutions by the lecturers but search for the required information from unlimited number of resources until finding the required answers and achieving the aimed level of knowledge. $(S, R, R, \& S, 2018)$.

The new innovative technology "Big Data" has been growing rapidly in the recent years, and it is being used and implemented in various sectors due to the benefits it adds to any sector uses it, big data nowadays is being used in healthcare sectors, in e-business, and in environmental sciences sector due to the effective ways of understanding facts it provides, as per the educational sector big data has just started its journey and it is gradually started to grow. In fact, the utilization of big data in the educational system can be very effective as it can help in improving the education delivery, it can help in taking better decisions as it provides decision support to the higher education institution management. (Bhat \& Ahmed, 2016).

Big Data in the higher education sector is aiming to enhance the learning and teaching methods. This can be done via using sensors and wearable smart devices in the classroom and record critical information from the students while taking a specific course via a specific teaching method such as their concentration level, or their brain activity, then analyze the big data collected, this would help enhancing the learning and teaching techniques by analyzing for example the best teaching method for a particular course, the best teaching method for various types of students with different IQ levels, its results can also show the effectiveness of some teaching and learning practices done in the classroom, and the benefits of using innovative technologies in the education system. (Bhat \& Ahmed, 2016), (West, 2012).

This research is simply an experimental utilization of the "EEG" device on a cohort of students from Middle East College, while they are taking a class, and the experiment targeted three different teaching and learning environments that already exist and implemented within the college's campus which are "Traditional Teaching \& Learning, Flipped Learning, and Collaborative Learning".

\section{Background About the Experiment}

\section{OmniFit Brainwave EEG}

The "OmniFit Brainwave EEG" is a user-friendly electroencephalography device that is used for the research and education purpose, this device was used on a cohort of students from each of the three previously mentioned teaching and learning environments. The time of the experiment on each student varies from " 25 minutes" to " 40 minutes".

As mentioned in the previous paragraph the experiment was demonstrated on three different teaching and learning environments existing within the Middle East College campus, following is an explanation of each of the three chosen environments:

- Traditional Teaching \& Learning: this method of teaching mainly relies on the lecturer. The lecturer is the centre of it, they are responsible of preparing the materials and subjects to be taught to the students, responsible of explaining these materials and providing the all of the needed knowledge to the students, whereas the students is such as an environment are only responsible of observing, processing, and analysing the knowledge and information given to them by their teachers. (UKEssays, 2016).

- Flipped Learning: in this style of teaching and learning the lecturer is no longer the centre of the classroom and the lecturer's role changes from being a teacher to be a facilitator and coach to the students. In this teaching and learning method the students will be provided with the required materials (ppt slides, videos made by the lecturer or a third party teacher) to gain a basic understanding and knowledge about their topics before starting the class, 
and once they be in their classroom they are required to practice, go in depth, and apply the concepts they have learned prior the class. (HEAcademy, 2017).

- Collaborative Learning: in this style of learning and teaching the students will form a group of two or more and work together to search, explore, and learn about the given topics by their teacher, as well as discuss among each other, with the class and their teacher about the materials, solutions and concepts they came up with and understood regarding their studied subject. (Smith \& MacGregor, 1992).

\section{Objectives of The Experiment}

\section{The experiment was aiming to achieve the followings:}

1. Discover the impact of "EEG" utilization in classrooms.

2. Determine the impact of various teaching and learning techniques on the students of Middle East College using Big Data Analytics.

3. Evaluate and compare between three different teaching environments.

4. Enhance the teaching and learning environments for the students and provide them with a better educational experience.

\section{About OmniFit Brainwave EEG}

OmniFit Brainwave EEG is a device that is used to provide real-time analysis on the brain status, it is a user-friendly, easy to use and a handy device, as it check the condition of the brain it gives the user with four different analysis readings it provides a reading for the brain's "Concentration, Stress, Activity, and Balance" levels while taking a class and learning.

\section{OMNIFIT BRAIN}

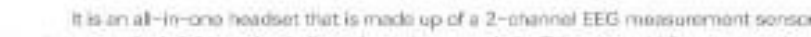

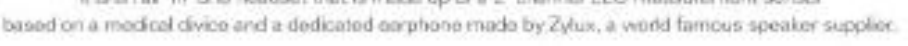

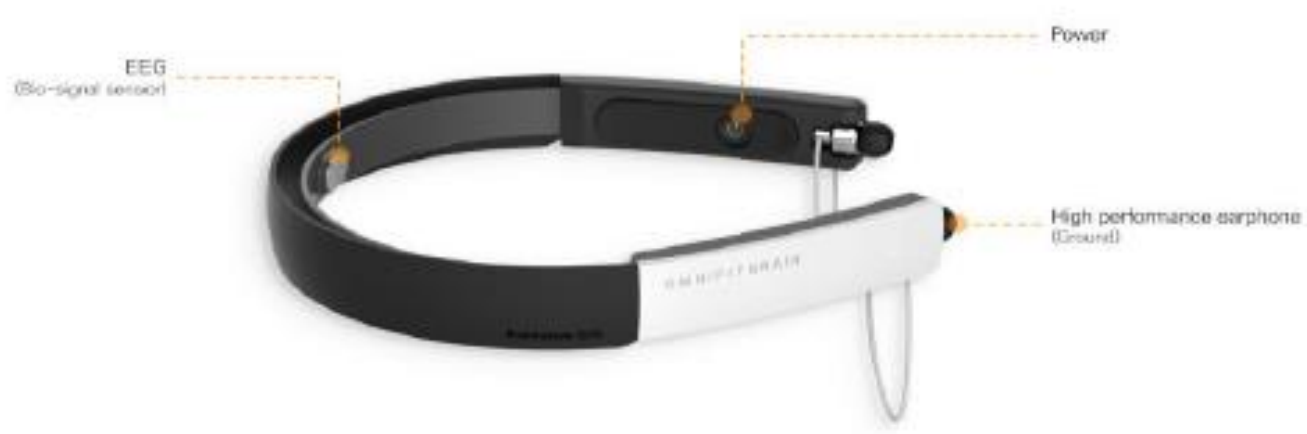

Figure 1. OmniFit Brainwave EEG 


\section{Journal of Student Research}

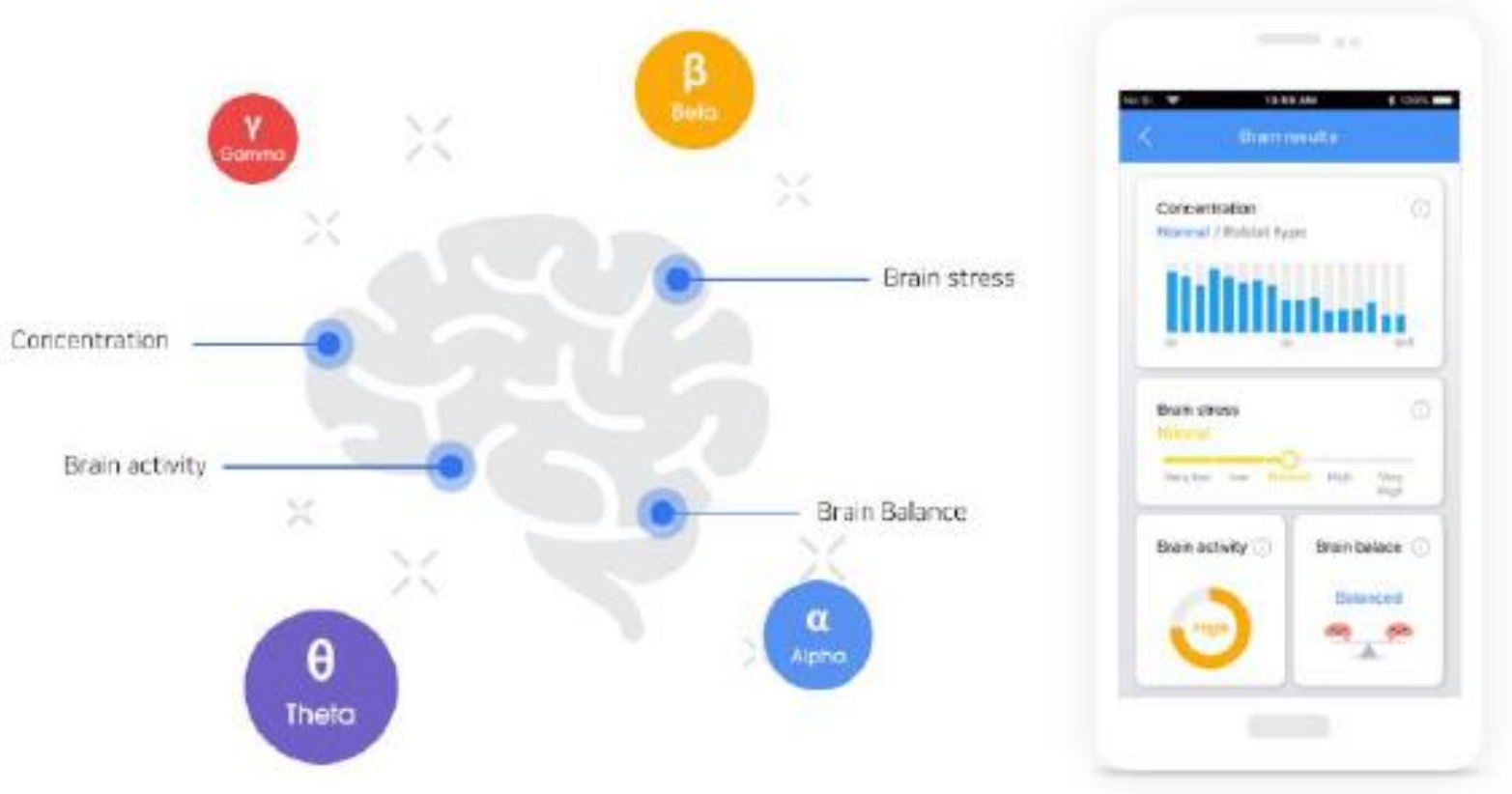

Figure 2. OmniFit Brainwave EEG Main Services

OmniFit Brainwave EEG comes with its own mobile application "OmniFit Brain: The Focus" which is supporting iOS and Android. The device gets connected with the application via Bluetooth, and once the EEG is placed on the student's forehead and the earphones are in the user can start the process of monitoring the brain's status of the student who is having the device on, and study their brain's condition state while taking a class. 


\section{Journal of Student Research}

Fourth Middle East College Student Research Conference, Muscat, Sultanate of Oman

\section{Bluetooth Headset Management}

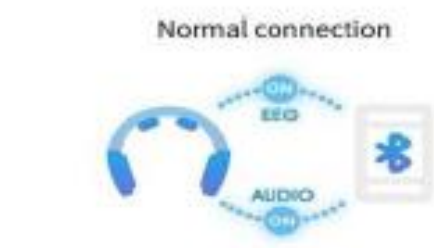

Connection management

EEG sensor

Con- $-120-9010$

Earphone(AUDIO)

comeat-thio

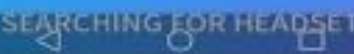

\section{Figure 3. OmniFit Brainwave EEG Bluetooth Paring}

After the EEG device is paired and connected with the phone's mobile application, the user then can start the brain condition's test by clicking on "AI Focus Assistant" option then pressing on "Start", and the test will start as shown in "Figure 4". 


\section{Journal of Student Research}

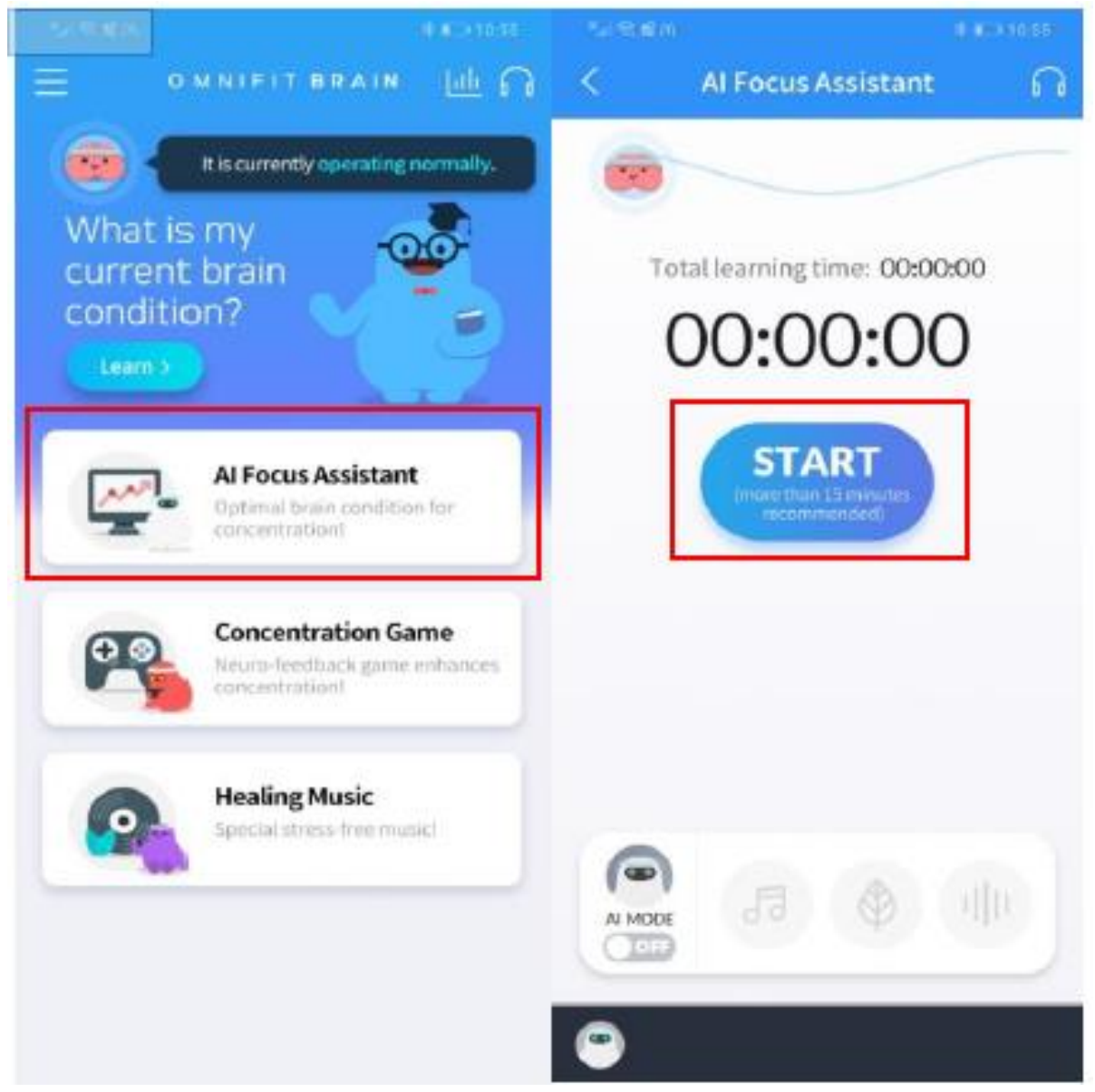

Figure 4. OmniFit Brainwave Mobile Application Dashboard

To get the analysis of the brain condition the test's period must be at least fifteen minutes long.

"Figure 5" shows the process of ending the test, first the user click on "Stop" option then clicks on "Confirm" after that the user will get the results of the brain's state analysis after the completion of the EEG test, as previously mentioned the "OmniFit Brainwave EEG" provides four different readings regarding the state of the brain which are the brain's concentration, activity, stress, and balance level. The application gives five different levels of results for each element, starting from the bottom the readings varies from "Very Low (0\% - 20\%), Low (21\% - 40\%), Average/Normal (41\% - 60\%), High (61\% - 80\%), and Very High (81\% - 100\%)". 


\section{Journal of Student Research}

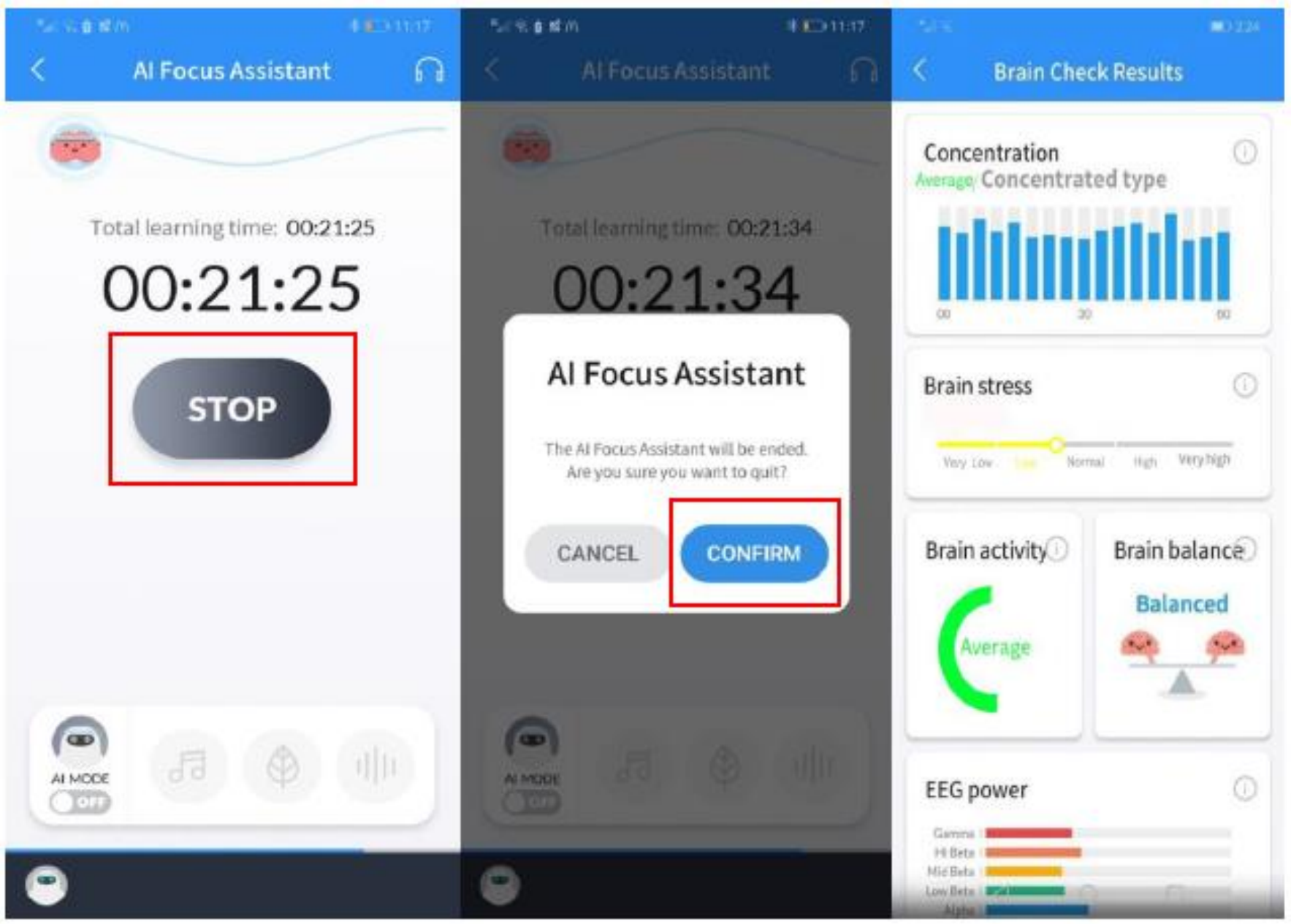

Figure 5. OmniFit Brainwave Brain Test Process

\section{Analysis of Data collected}

The data which was collected using the method described meticulously in the introduction section of this research work was methodically analyzed using a professional analysis tool SPSS. The data pertains to three different sessions of the same students who were monitored during their sessions which were conducted using different teaching and learning methodological approaches i.e. Traditional Teaching, Flipped Learning and Collaborative Learning methods. There are three significant brain activity and concentration levels which were recorded while students were handled with different teaching methods. Three parameters were monitored using the device as already explained in the above sub-section of the paper, these parameters are "Brain Concentration level", "Brain Activity" and "Brain Stress Level". The below analyses showcases the performance of each method of teaching and learning with respect to the session that was monitored. The below provided figures show the brain activity with respect to each of the teaching and learning methods. 


\section{Journal of Student Research}

Fourth Middle East College Student Research Conference, Muscat, Sultanate of Oman

\begin{tabular}{|c|c|c|c|c|}
\hline \multicolumn{5}{|c|}{ Brain Concentration Level * Teaching Methodology Cross tabulation } \\
\hline & & & \multicolumn{2}{|c|}{ Teaching Methodology } \\
\hline & & & $\begin{array}{l}\text { Traditional } \\
\text { Teaching }\end{array}$ & $\begin{array}{l}\text { Flipped } \\
\text { Learning }\end{array}$ \\
\hline \multirow{18}{*}{$\begin{array}{l}\text { Brain Concentration } \\
\text { Level }\end{array}$} & \multirow[t]{2}{*}{$35 \%$} & Expected Count & 3.3 & 3.3 \\
\hline & & $\begin{array}{l}\text { \%o within Brain Concentration } \\
\text { Level }\end{array}$ & $0.0 \%$ & $100.0 \%$ \\
\hline & \multirow[t]{2}{*}{$45 \%$} & Expecied Count & 3.0 & 3.0 \\
\hline & & $\begin{array}{l}\% \text { within Brain Concentration } \\
\text { Level }\end{array}$ & $0.0 \%$ & $100.0 \%$ \\
\hline & \multirow[t]{2}{*}{$50 \%$} & Expected Caunt & 6.0 & 6.0 \\
\hline & & $\begin{array}{l}\text { \%o within Brain Concentration } \\
\text { Level }\end{array}$ & $33.3 \%$ & $61.1 \%$ \\
\hline & \multirow[t]{2}{*}{$55 \%$} & Expected Caunt & 1.7 & 1.7 \\
\hline & & $\begin{array}{l}\text { \% within Brain Concentration } \\
\text { Level }\end{array}$ & $100.0 \%$ & $0.0 \%$ \\
\hline & \multirow[t]{2}{*}{$65 \%$} & Expected Count & 3.3 & 3.3 \\
\hline & & $\begin{array}{l}\text { \% within Brain Concentration } \\
\text { Level }\end{array}$ & $100.0 \%$ & $0.0 \%$ \\
\hline & \multirow[t]{2}{*}{$70 \%$} & Expected Count & 3.0 & 3.0 \\
\hline & & $\begin{array}{l}\text { To within Brain Concentration } \\
\text { Level }\end{array}$ & $100.0 \%$ & $0.0 \%$ \\
\hline & \multirow[t]{2}{*}{$75 \%$} & Expected Count & 3.0 & 3.0 \\
\hline & & $\begin{array}{l}\% \text { within Brain Concentration } \\
\text { Level }\end{array}$ & $0.0 \%$ & $0.0 \%$ \\
\hline & \multirow[t]{2}{*}{$80 \%$} & Expected Count & 3.7 & 3.7 \\
\hline & & $\begin{array}{l}\% \text { within Brain Concentration } \\
\text { Level }\end{array}$ & $0.0 \%$ & $0.0 \%$ \\
\hline & \multirow[t]{2}{*}{$85 \%$} & Expected Caunt & 3.0 & 3.0 \\
\hline & & $\begin{array}{l}\text { \%o within Brain Concentration } \\
\text { Level }\end{array}$ & $0.0 \%$ & $0.0 \%$ \\
\hline \multirow{2}{*}{\multicolumn{2}{|c|}{ Total }} & Expected Count & 30.0 & 30.0 \\
\hline & & $\begin{array}{l}\text { \% within Brain Concentration } \\
\text { Level }\end{array}$ & $33.3 \%$ & $33.3 \%$ \\
\hline
\end{tabular}

Figure 6. Brain Concentration Level * Teaching Methodology Cross Tabulation 


\section{Journal of Student Research}

Fourth Middle East College Student Research Conference, Muscat, Sultanate of Oman

\begin{tabular}{|c|c|c|c|c|}
\hline \multicolumn{5}{|c|}{ Brain Concentration Level * Teaching Methodology Cross tabulation } \\
\hline & & & \multirow{3}{*}{$\begin{array}{l}\text { Teaching } \\
\text { Methodology } \\
\text { Collaborative } \\
\text { Learning }\end{array}$} & \multirow[t]{3}{*}{ Total } \\
\hline & & & & \\
\hline & & & & \\
\hline \multirow[t]{18}{*}{ Brain Concentration Level } & \multirow[t]{2}{*}{$35 \%$} & Expected Count & 3.3 & 10.0 \\
\hline & & $\begin{array}{l}\text { \% within Brain Concentration } \\
\text { Level }\end{array}$ & $0.0 \%$ & $100.0 \%$ \\
\hline & \multirow[t]{2}{*}{$45 \%$} & Expected Count & 3.0 & 9.0 \\
\hline & & $\begin{array}{l}\% \text { within Brain Concentration } \\
\text { Level }\end{array}$ & $0.0 \%$ & $100.0 \%$ \\
\hline & \multirow[t]{2}{*}{$50 \%$} & Expected Count & 6.0 & 18.9 \\
\hline & & $\begin{array}{l}\% \text { within Brain Concentration } \\
\text { Level }\end{array}$ & $5.6 \%$ & $100.0 \%$ \\
\hline & \multirow[t]{2}{*}{$55 \%$} & Expected Count & 1.7 & 5.0 \\
\hline & & $\begin{array}{l}\% \text { within Brain Concentration } \\
\text { Level }\end{array}$ & $0.0 \%$ & $100.0 \%$ \\
\hline & \multirow[t]{2}{*}{$65 \%$} & Expected Count & 3.3 & 10.0 \\
\hline & & $\begin{array}{l}\% \text { within Brain Concentration } \\
\text { Level }\end{array}$ & $0.0 \%$ & $100.0 \%$ \\
\hline & \multirow[t]{2}{*}{$70 \%$} & Expected Count & 3.0 & 8.0 \\
\hline & & $\begin{array}{l}\text { \% within Brain Concentration } \\
\text { Level }\end{array}$ & $0.0 \%$ & $100.0 \%$ \\
\hline & \multirow[t]{2}{*}{$75 \%$} & Expected Count & 3.0 & 9.0 \\
\hline & & $\begin{array}{l}\% \text { within Brain Concentration } \\
\text { Level }\end{array}$ & $100.0 \%$ & $100.0 \%$ \\
\hline & \multirow[t]{2}{*}{$80 \%$} & Expected Count & 3.7 & 11.0 \\
\hline & & $\begin{array}{l}\% \text { within Brain Concentration } \\
\text { Level }\end{array}$ & $100.0 \%$ & $100.0 \%$ \\
\hline & \multirow[t]{2}{*}{$85 \%$} & Expected Count & 3.0 & 9.0 \\
\hline & & $\begin{array}{l}\% \text { within Brain Concentration } \\
\text { Level }\end{array}$ & $100.0 \%$ & $100.0 \%$ \\
\hline \multirow{2}{*}{\multicolumn{2}{|c|}{ Total }} & Expected Count & 30.0 & 90.0 \\
\hline & & $\begin{array}{l}\% \text { within Brain Concentration } \\
\text { Level }\end{array}$ & $33.3 \%$ & $100.0 \%$ \\
\hline
\end{tabular}

Figure 7. Brain Concentration Level * Teaching Methodology Cross Tabulation 


\section{Journal of Student Research}

Fourth Middle East College Student Research Conference, Muscat, Sultanate of Oman

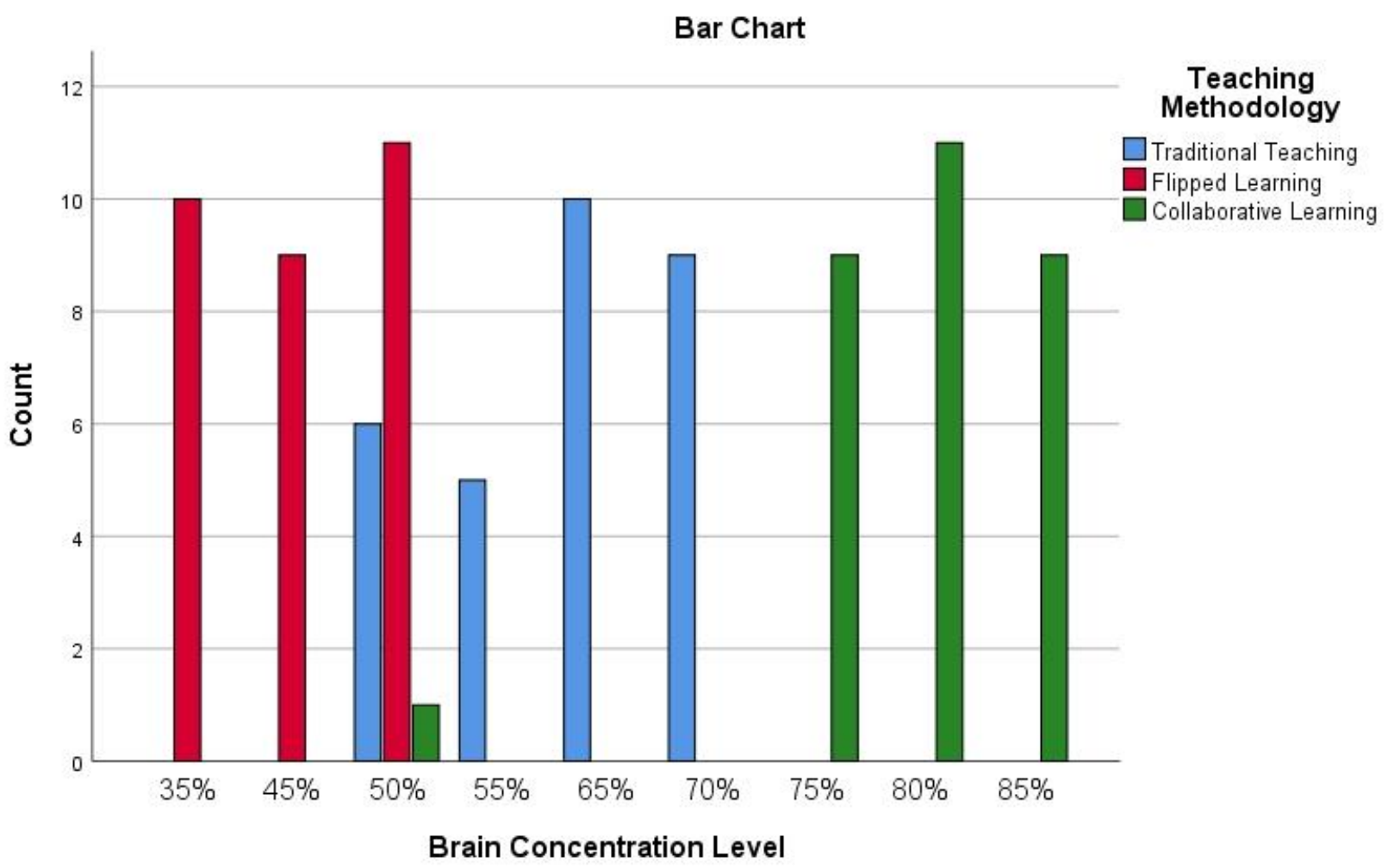

Figure 8. Brain Concentration Levels 


\section{Journal of Student Research}

Fourth Middle East College Student Research Conference, Muscat, Sultanate of Oman

\begin{tabular}{|c|c|c|c|c|c|}
\hline & & & \multicolumn{3}{|c|}{ Teaching Methodology } \\
\hline & & & $\begin{array}{l}\text { Traditional } \\
\text { Teaching }\end{array}$ & $\begin{array}{l}\text { Flipped } \\
\text { Learning }\end{array}$ & $\begin{array}{c}\text { Collaborative } \\
\text { Learning }\end{array}$ \\
\hline \multirow[t]{18}{*}{ Brain Activity Level } & $20 \%$ & Expected Count & 3.3 & 3.3 & 3.3 \\
\hline & & $\%$ within Brain Activity Level & $0.0 \%$ & $100.0 \%$ & $0.0 \%$ \\
\hline & $30 \%$ & Expected Count & 1.7 & 1.7 & 1.7 \\
\hline & & $\%$ within Brain Activity Level & $0.0 \%$ & $100.0 \%$ & $0.0 \%$ \\
\hline & $35 \%$ & Expected Count & 3.7 & 3.7 & 3.7 \\
\hline & & $\%$ within Brain Activity Level & $0.0 \%$ & $100.0 \%$ & $0.0 \%$ \\
\hline & $40 \%$ & Expected Count & 6.3 & 6.3 & 6.3 \\
\hline & & $\%$ within Brain Activity Level & $100.0 \%$ & $0.0 \%$ & $0.0 \%$ \\
\hline & $45 \%$ & Expected Count & 3.3 & 3.3 & 3.3 \\
\hline & & $\%$ within Brain Activity Level & $60.0 \%$ & $40.0 \%$ & $0.0 \%$ \\
\hline & $50 \%$ & Expected Count & 2.0 & 2.0 & 2.0 \\
\hline & & $\%$ within Brain Activity Level & $83.3 \%$ & $0.0 \%$ & $16.7 \%$ \\
\hline & $75 \%$ & Expected Count & 3.0 & 3.0 & 3.0 \\
\hline & & $\%$ within Brain Activity Level & $0.0 \%$ & $0.0 \%$ & $100.0 \%$ \\
\hline & $80 \%$ & Expected Count & 3.0 & 3.0 & 3.0 \\
\hline & & $\%$ within Brain Activity Level & $0.0 \%$ & $0.0 \%$ & $100.0 \%$ \\
\hline & $85 \%$ & Expected Count & 3.7 & 3.7 & 3.7 \\
\hline & & $\%$ within Brain Activity Level & $0.0 \%$ & $0.0 \%$ & $100.0 \%$ \\
\hline \multirow[t]{2}{*}{ Total } & & Expected Count & 30.0 & 30.0 & 30.0 \\
\hline & & $\%$ within Brain Activity Level & $33.3 \%$ & $33.3 \%$ & $33.3 \%$ \\
\hline
\end{tabular}


Figure 9. Brain Activity Levels

\begin{tabular}{|c|c|c|c|}
\hline \multicolumn{4}{|c|}{ Brain Activity Level * Teaching Methodology Cross tabulation } \\
\hline & & & Total \\
\hline \multirow[t]{15}{*}{ Brain Activity Level } & \multirow[t]{2}{*}{$20 \%$} & Expected Count & 10.0 \\
\hline & & $\%$ within Brain Activity Level & $100.0 \%$ \\
\hline & \multirow[t]{2}{*}{$30 \%$} & Expected Count & 5.0 \\
\hline & & $\%$ within Brain Activity Level & $100.0 \%$ \\
\hline & \multirow[t]{2}{*}{$35 \%$} & Expected Count & 11.0 \\
\hline & & $\%$ within Brain Activity Level & $100.0 \%$ \\
\hline & \multirow[t]{2}{*}{$40 \%$} & Expected Count & 19.0 \\
\hline & & $\%$ within Brain Activity Level & $100.0 \%$ \\
\hline & \multirow[t]{2}{*}{$45 \%$} & Expected Count & 10.0 \\
\hline & & $\%$ within Brain Activity Level & $100.0 \%$ \\
\hline & \multirow[t]{2}{*}{$50 \%$} & Expected Count & 6.0 \\
\hline & & $\%$ within Brain Activity Level & $100.0 \%$ \\
\hline & \multirow[t]{2}{*}{$75 \%$} & Expected Count & 9.0 \\
\hline & & $\%$ within Brain Activity Level & $100.0 \%$ \\
\hline & $80 \%$ & Expected Count & 9.0 \\
\hline & & $\%$ within Brain Activity Level & $100.0 \%$ \\
\hline & \multirow[t]{2}{*}{$85 \%$} & Expected Count & 11.0 \\
\hline & & $\%$ within Brain Activity Level & $100.0 \%$ \\
\hline \multirow{2}{*}{\multicolumn{2}{|c|}{ Total }} & Expected Count & 90.0 \\
\hline & & $\%$ within Brain Activity Level & $100.0 \%$ \\
\hline
\end{tabular}

Figure 10. Brain Activity Level * Teaching Methodology Cross Tabulation

Figure 11. Brain Activity Levels

Figure 12. Brain Stress Level * Teaching Methodology Cross Tabulation

Figure 13. Brain Stress Level * Teaching Methodology Cross Tabulation

Figure 14. Brain Stress Levels

\section{Conclusion and Future Work}




\section{Journal of Student Research}

Fourth Middle East College Student Research Conference, Muscat, Sultanate of Oman

This research work is primarily intended to enhance student experience through the use of IoT and big data analytics. The researchers intend to show a prototype of a larger implementation of IoT and big data analytics which can provide preemptive and predictive capabilities for the higher education institution administration for better decision making and in addition support educationalist in their delivery by providing insights to the facts which otherwise remain hidden from the academicians. The data collected at a very small scale in a cohort of 30 students is just used to provide an idea that same method can be applied to a larger sample to infer and yield lot of beneficial conclusions. The research work certainly showcases a way in which modern technologies like big data and IoT can assist higher education institutions to plan for the future and also assist academicians in their delivery for enhanced student experience. Although this research work only takes into consideration three parameters which are pertaining to the brain activity of the students however lot of other parameters can be taken into consideration which may provide lot of fruitful information and facts critical for future development of the institutions. This research activity just uses one of the sensing devices to monitor the concentration levels of students, however many more sensors comparatively much more advanced than the one used for this research can be utilized to get beneficial results.

This research work has the limitation as the sample size of the population on which data collection was done is not large moreover the parameters that have been calculated and analyzed are very less in number which do not provide sufficient facts to given strong conclusions and preemptive and predictive capabilities however this work has a huge scope for improvement and can be conducted at a much larger scale with appropriate resources, planning and expected outcomes.

\section{Acknowledgements}

All praise and glory to Almighty for bestowing the ability and knowledge to conduct this research work. I thank Middle East College in Sultanate of Oman for their continued support and cooperation, I am thankful to the management of Middle East College for providing a conducive environment for research and for supporting and sponsoring research activities. I am also indebted to my supervisor for his painstaking efforts to support this work without whom it would not have been possible. I am thankful to my biggest supporter, my friends, colleagues and family members who supported and encouraged me throughout this research work.

\section{References}

1. Al-Awar, D. (2015). The Quality and Future of Higher Education. 1st ed. Dubai: Hamad Bin Mohammed Smart University Publishing House.

2. Bhat, A. and Ahmed, I. (2016). Big data for institutional planning, decision support and academic excellence. 2016 3rd MEC International Conference on Big Data and Smart City (ICBDSC). Available at: https://ieeexplore.ieee.org/abstract/document/7460353.

3. HE Academy. 2017. Flipped learning. Available at: https://www.heacademy.ac.uk/knowledgehub/flipped-learning-0.

4. UK Essays. 2016. TRADITIONAL VERSUS MODERN METHODS OF EFFECTIVE TEACHING. Available at:

https://www.ukessays.com/essays/education/traditional-versus-modern-methods-of-effectiveteaching-education-essay.php.

5. Singh, A., Raghunathan, S., Robeck, E. and Sharma, B. (2018). Cases on Smart Learning Environments. 1st ed. Dubai.

6. West, D. (2012). Big Data for Education: Data Mining, Data Analytics, and Web Dashboards. Insidepolitics. Available at: http://www.insidepolitics.org/brookingsreports/education\%20big\%20data.pdf.

7. Leigh Smith \& T. MacGregor, B., 1995. What is Collaborative Learning?. Washington Center for Improving the Quality of Undergraduate Education. Available at:

https://www.evergreen.edu/sites/default/files/facultydevelopment/docs/WhatisCollaborativeL 
earning.pdf. 